\title{
Assessing the Factors Influencing Entrepreneurial Intention Among Undergraduates Students: Evidence from the School of Agriculture and Agricultural Technology, Federal University of Technology, Akure, Nigeria
}

\author{
Edamisan OLOWOFESO \\ Department of Entrepreneurship, School of Management Technology, The Federal University of \\ Technology, Akure, Nigeria. \\ eolowofeso@futa.edu.ng,_www.orcid.org/0000-0001-6927-2600
}

\begin{abstract}
Entrepreneurship has been recognised as the backbone of the economic development of any nation. It is one of the ways of providing job opportunities for people. The objectives of the study are to examine the factors influencing the Entrepreneurial Intention (EI) of the students of Agriculture and Agricultural Technology toward entrepreneurship. The population of the study comprised of all the final year students in the School of Agriculture and Agricultural Technology, the Federal University of Technology Akure, Nigeria. Stratified sampling techniques were used to divide the School into eight Departments. Each of the Departments was considered as strata for the study. A structured questionnaire was used to collect information about the EI of the students. 40 copies of the questionnaires were randomly distributed to the students in each of the eight departments. A total of 320 copies of questionnaires were distributed and 231 copies were retrieved for analysis. Items on the questionnaire were rated on a Likert-type scale with five possible responses from 1- strongly disagree to 5- strongly agree. Both descriptive and inferential statistics were used for the study. The result of linear regression analysis revealed that all the independent variables have significant effect on EI with $\mathrm{P}<0.05$. The results of the study concluded that behavioural factors are possible determinants of students' EI. The study recommended that both the government and individual need to support the entrepreneurs by investing in enterprise education.
\end{abstract}

Keywords: Attitudinal factor, entrepreneurial intention, entrepreneurship education, perceived behavioural control, subjective norms. 


\section{Introduction}

In the last two decades, Entrepreneurship has been considered as the backbone of economic development of any nation. Thus, it has conquered the cardinal theme of academics and governmental policymakers' interest. Nigeria like other countries of the world is confronted with numerous challenges which include unemployment and poverty (Amzad, Naser \& Zaman, 2009). These circumstances posture awesome challenges to the exceptionally presence of people in most developing countries in this manner calling for the preparation of taught individuals who can work successfully within the society in which they live. The failure of the government to provide job opportunities for its citizen and her performance within the global economy brought about the introduction of entrepreneurship education into the educational programmes of Nigeria tertiary education in the 2007/2008 academic session (Ayatse, 2013; Amadi \& Amakodi, 2019). The policy introduced mandatory entrepreneurship courses that would span two semesters to all undergraduate students in tertiary institutions in respective of their discipline to build the capacity of youths to empower, identify and exploit opportunities in the environment (Okojie, 2009). To achieve this, a center for entrepreneurship studies to facilitate the programme was built up in almost all tertiary institutions in Nigeria. The programme was established to building knowledge and skills either "about" or "for" entrepreneurship generally as part of recognised education programmes at primary, secondary and tertiary levels.

Furthermore, creating entrepreneurial aptitudes among citizens was one of the objectives of the Nigerian vision 2020 (National Implementation Plan, 2010). To solve the problem of unemployment among graduates, different suggestions have been raised by policymakers and academicians in other for these graduates to be self-employed. The majority of the new graduates do have the information and ability that are critical for starting-up their trades, just a few numbers of them were self-employed promptly after graduating (Amadi \& Amakodi, 2019). This may be due to lack of self-confidence or support from either government or private individuals. There may be others who are potential business visionaries but are not appropriately mindful of the career choices that are open to them. Their purpose of getting self-employed had provoked analysts to examine especially on the impact of entrepreneurial characteristics and EI among undergraduates towards entrepreneurial activities.

Owing to the perseverance of mass unemployment, low productivity, high inflation, and widespread poverty in Nigeria, many policy trusts and programmes to advance abilities procurement, facilitate the spirit of creativity, self-reliance has been presented by the government of Nigeria. These include Subsidy Re-investment Employment Programme (Sure-P), National Poverty Eradication Programme (NAPEP), National Directorate of Employment (NDE), National Economic Empowerment and Development Strategies (NEEDS), National Poverty Eradication Program (NAPEP), Small and Medium Enterprises Development Agency of Nigeria (SMEDAN) and the New Partnership for Africa's Development (NEPAD) (Osibanjo, 2006 as cited in Awogbenle \& Iwuamadi, 2010; Egbefo \& Abe, 2017). However, the circumstance has not changed the desired direction. Since these programmes only address the output, a complementary approach is required. The educational system that addresses the output conclusion either lays more accentuation on substance and information securing for its purpose or fair stresses the inquiry-discovery demonstrate of educating and learning (Egbefo \& Abe, 2017).

Muhammad, Aliyu, Sirajo and Ahmed (2015) noted that despite the career direction through entrepreneurial agricultural courses for students, it takes a longer period for many of them to secure a job. This reflects either the students are not having the interest of being self-employed or they are 
having other constraints to becoming what they have learned from their course of study in the school. Hence this study accesses the students of Agriculture if they are willing to take up and put to practice all they have been thought as students of agriculture instead of seeking white-collar jobs if they are willing to be an employer of labour by creating wealth and employment opportunities. This study looks at some factors that affect the intention of agricultural science students towards entrepreneurship. The study is streamlined to the students that study agricultural sciences in the Federal University of Technology Akure, Nigeria using the final year students of the School of Agriculture and Agricultural Technology (SAAT) as the respondents. The study considered the Entrepreneurship Education (EE), Attitudinal factors (ATT), Subjective Norms (SN), and Perceived Behavioural Control (PBC) of the students as independent variables and Entrepreneurial Intentions (EI) as the dependent variable.

\section{Objective and Hypotheses formulation}

In other to examine the EI of the study in the study area, the following four hypotheses developed;

$\mathrm{H}_{01}$ Entrepreneurship Education does not have significant effect on the EI of the students,

$\mathrm{H}_{02}$ Attitude factors does not have a significant effect on student's EI,

$\mathrm{H}_{03}$ Subjective norms do not have a significant effect on EI of the students, and

$\mathrm{H}_{04}$ Perceived behavioural control does not significantly affect EI among students.

\section{Literature review}

\section{Concept of Entrepreneurial Intention (EI)}

Entrepreneurial intention is identical to individual competency that refers to a willingness to conduct a certain behaviour (Rizki, Burhanuddin \& Budi, 2017). The intention is an acceptance of a representative relationship. Arbuthnott (2008) observed that strong effect of intention to behaviour as "the more personal and specific our intentions are, the more likely they are to influence our behaviour". In this regard, EI can be determined based on the degree of willingness and ability of an individual or group of persons to set up a business in the future. EI serves as the dependent variable of the model and it has been used by previous studies (Gelderen, Brand, Praag, Bodewes, Poutsma, \& Vangils, 2008; Ali, Lu \& Wang, 2012; Emmanuel, Adejoke, Olugbenga \& Olatunde, 2012). The model links independent variables (Attitude, perceived behavioural control, and subjective norms) with the dependent variable to assess the EI of undergraduate students.

\section{Entrepreneurship education}

Entrepreneurship education is the advancement of entrepreneurial aptitudes, successful and effective application of the aptitudes within the management of a business to form a critical distinction from other businesses, recognising the abilities and permitting it to operate successfully (Odoemelam \& Maduka, 2017). Alberti, Scisscia and Poli (2004) defined entrepreneurship education as the organised formulae movement of business competencies which in turn refers to the concept, abilities and mental mindfulness utilized by people amid the method of beginning and creating their growth-oriented ventures. In the same perspective, Ayeduse (2011) supports that entrepreneurship education will provide meaningful education for undergraduates which could make them become self-reliant and provide them with creative and innovative skills necessary for identifying new business opportunities. Entrepreneurship education is the sort of instruction planned to alter the introduction and state of mind of the beneficiaries and the method will prepare them with the abilities 
and information to empower them to begin and manage a trade. It points at creating the imperative entrepreneurial abilities, attitudes, competencies, and dispositions that will incline the person to start his own new business (Agu, 2006).

\section{Attitudinal Factors}

High attitudes of people with attitudinal inclinations towards the financial compensation, sense of achievement, freedom, competitiveness, are considered strong prospective entrepreneurs (Douglas \& Fitzsimmons, 2005). A fundamental identity characteristic just like they require for accomplishment can impact an individual's towards EI (Fayolle \& Gailly, 2015). Ajzen (2005) noted that attitudes can be measured by two indicators: experiential and instrumental attitudes. According to Wan, Shen and Yu (2014) experimental attitude depends on the previous experiences of a person or how an individual evaluates their overall experiences positively or negatively. When a previous action's result is positive or good, it gives a positive signal to them and vice versa. On the other hand, when an individual learns any attitude it is called instrumental attitude. The experiential and instrumental attitude in the sense of entrepreneurship is the knowledge and transition of the human experience in conducting business activities. When individuals gets positive and they benefit from the experience and translation of entrepreneurship, it helps to get a positive response from the individual, and vice versa (Purusottama, 2019), and attitude can be changed due to change in beliefs (Liñán \& Fayolle, 2015). Thus, in entrepreneurial activities when an individual produces or learns a positive or negative response it is called an entrepreneurial attitude (Liñán \& Fayolle, 2015).

\section{Perceived Behavioural Control (PBC)}

Perceived behavioural control (PBC) alludes to components that will either encourage or hinder the execution of conduct. Numerous important studies have been conducted on PBC such as Kristiansen and Indarti (2004); Usman and Yennita (2019); Nahida and Md (2020). With particular reference to entrepreneurship, it reveals the perceived ease or difficulty of setting up a new business venture $\mathrm{Wu}$ $\& \mathrm{Wu}, 2008)$. In addition, PBC refers to the level of difficulty for an individual to be an entrepreneur (Liñán \& Fayolle, 2015). Potishuk and Kratzer (2017) noted that entrepreneurial PBCs of individuals strongly influence individuals toward entrepreneurship. It ties in with self-efficacy which alludes to an individual's discernment towards his capacity to perform a task and is important in the development of intention (McGee, Peterson, Mueller \& Sequeira, 2009). Intentions and their attitudinal antecedents are based on perceived notions. As such, they are not fixed elements grounded since an individual's formative years but can be learned and mounded through one's life. Self-efficacy too influences an individual's conviction on whether he can accomplish his objectives (Cromie, 2000).

This supports the establishment of human inspiration towards accomplishing one's objectives. A person who accepts that he can get the required results from his activities will be profoundly incentivised (and propelled) to act and drive forward in the midst of troubles (Pajares, 2002). Bandura's social theory further states that an individual's level of inspiration and his coming about activities are based more on his convictions than on what may or may not be justifiably genuine. Given a solid discernment of self-efficacy, a person can be enormously affected by acting on a deliberate and will use accessible information and aptitudes towards the specific conduct or objective. 


\section{Subjective Norms}

Subjective norm refers to the perceived social normative pressures due to environmental factors and other relevant beliefs to perform certain behaviour or not ((Liñán \& Chen 2009, Ajzen, 2005). This can also be subjective as a result of the inferences influenced by the immediate community (e.g. guardians, spouse, friends, religious leaders, and teachers). Mohammed and Aparna, (2011) have demonstrated the significance of subjective standards in students' choice of their career inclination. Hence, stand-ins are likely to be self-employed after graduation when their immediate contacts are in support to become entrepreneurs.

\section{Theories underpinning the study}

Different theories such as Theory of Reasoned Action (TRA), Theory of Planned Behavior (TPB) have been used in the literature as a guide to the study of EI. However, one of the strong theoretical foundations that have been used to explain the EI in the previous studies by entrepreneurship researchers is the TPB (Fayolle, Gailly \& Lassas-Clerc, 2006; Kolvereid \& Isaksen, 2006; Gelderen, et al., 2008; Liñán \& Chen, 2009; Liñán \& Fayolle, 2015; Aloulou (2016; Entrialgo \& Iglesias, 2016; Farooq, Salam, Fayolle, Jaafar \& Ayupp, 2018; Al-Jubari, 2019). TPB focuses on organizational or individuals behavior that is influenced by different factors such as entrepreneurship education, attitudinal factor, subjective norms and perceived behavioural control. In addition, TPB was developed by Icek -Ajzen in 1991 as an improvement to the TRA to study the behavior of organisations or individuals. However, TPB was chosen in this study because it has been tested and it is becoming an essential instrument to measure human behavior across different subjects including entrepreneurship (Farooq et al., 2018; Aloulou, 2016). The interaction between environmental and personal factors is effectively explained in this theory (Sivarajah, \& Achchuthan, 2013). The antecedents of the factors used in this theory; entrepreneurship education, attitudinal factor, subjective norms and perceived behavioural control impacts the behaviour and the work as predictors of an individuals' preparation (Ajzen, 1991; Liñán, 2004). The greater the desire to participate in a specific action, the higher the chance that it will eventually end up practicing that particular behavior.

According to Ajzen (2005), the preceding activity of performing a specific behavior is the intention of the individual to perform the behavior, the stronger the intention towards the behavior, the more possibility of success of the actual behavior. Furthermore, most planned behaviors are predicted only by their intentions (Krueger, Reilly \& Carsrud, 2000; Kolvereid \& Isaksen, 2006; Al-Jubari, 2019). According to De- Pillis and Reardon (2007), EI is, "the intention to start the business." On the other hand, Wilson, Kickul and Marlino (2007) noted that it is a conscious and deliberate decision for an individual to become an entrepreneur and to start his own new business and requires time, planning and high cognitive processing (Ozaralli \& Rivenburgh, 2016). That's why a career decision to be an entrepreneur is also considered as a planned behavior that can be expelled by the intention model TPB. TPB suggested three interconnected factors that can help to predict EI due to their antecedent and close influence EI, attitudes (personal positive/negative assessment of entrepreneurship), subjective norms (approval or disapproval of action by significant others), and PBC (perception of one's abilities to perform entrepreneurially) (Ajzen \& Sheikh, 2016).

\section{Empirical evidence of the study}

Empirical evidence by Rizki, Burhanuddin and Budi (2017) investigated entrepreneurship intention within the agricultural sector of the young generation in Indonesia. The research was conducted in three cities, Bogor, Lampung and Bandung with 189 respondents. The accumulated data were then 
analysed using descriptive analysis and the structural equation model. Respondents have highly average trends on behaviour belief, normative belief, motivation to comply, control belief, control belief power, and intention. The study revealed that only the evaluation of the consequence to give the medium trend is about 50.26 percent. The study concluded that subjective norms or external factors are factors that affect entrepreneurship intention in the agricultural sector, while attitude toward behaviour and perceived behavioural control factors do not affect entrepreneurship intention in the agricultural sector.

Furthermore, the empirical studies by Zaki, Abdul, Kushairi and Fansuri (2017) examined the perception of a total of 400 graduates from five Universities throughout Malaysia, to determine factors influencing them to pursue careers in the agricultural sector in the future. The quantitative study adopted by the study established measurement for investigating the relationship between personality traits and agribusiness EI among the students. Personality traits, conceptualized into two dimensions, namely, risk-taking and innovativeness demonstrated Cronbach's Alpha values of 0.80 and 0.73 , respectively. The study showed both variables had a positive association with agribusiness EI.

Moreover, Nematoollah, Davoud and Seyed (2012) investigated environmental factors that affect the EI of agriculture students at Ilam University. The population of the study was all of the agricultural fourth-year undergraduate students in the University of Ilam, 100 persons were selected for study by adoptions proportionate stratified random sampling method. The study showed a significant positive relationship between the variables of role model, social support, and perceived desirability with EI of students. The result of the analysis showed that the perceived desirability variable has the most impact on the students' EI while the changing social norms had less impact on students' EI.

Ehsan, Naser, Khadijeh and Mohammadreza (2016) conducted a study to determine the extent of EI among senior agricultural students and to identify the main factors influencing their intentions. The population of the study comprised all senior agricultural students who were studying in Shiraz University, Shiraz, Iran. A sample of 196 students was selected through stratified random sampling. The results of the study revealed that subjective norms, perceived behavioural control, and attitude toward entrepreneurship strongly correlated with students' EI.

Also, Muhammad et al., (2015) conducted a study on EI among Nigerian University students". it was found that entrepreneurial attitude, subjective norm, and power of behavioural control are all significant predictors EI. The result shows that the model used has significant implications for policymakers and other stakeholders that want to enhance entrepreneurial ability among University students in Nigeria. The determining factors such as attitude and subjective norms should receive attention since they have a direct effect on the EI of the respondents. Also it was stated that entrepreneurial education and training need to be enhanced further to increase awareness and change the mind-set of the respondents toward imbibing the entrepreneurial culture and reduce complete reliance on government and other formal sectors.

Siyanbola, Afolabi, Jesuleye, Egbetokun, Dada, Aderemi, Sanni and Razak (2009) also wrote on "Determinants of the entrepreneurial propensity of Nigeria undergraduates: by using a pilot survey in the Federal University and a State Polytechnic in the South Western Region of the country, The study discovered that some useful conclusions were derived, which is very important to note that, entrepreneurial interest among Nigerian students is quite high but the expression of this interest in practice is rather low. The study reveals that female undergraduate students are less curious about 
enterprise when compared with their male partners. It was moreover found that certain family financial characteristics, trade history, and income significantly stimulate the entrepreneurial interest of the students. Entrepreneurial education plays a significant role in entrepreneurship as students who had taken the entrepreneurship course are more likely to be interested in start-up.

Yeboah, Kumi and Jacob (2013) conducted research on assessment of entrepreneurship intention among Sunyani Polytechnic Marketing Students. The study examined marketing student's intention to pursue entrepreneurship, the determinants of the intentions, motivators of intention, and obstacles to intentions. The findings have shown that there is a high intention and that students are interested to become entrepreneurs. There are motivators and obstacles to entrepreneurship intentions in the country.

Kenneth, Godday and Michael, (2013) investigated "Factors impacting EI among graduates of Nigerian tertiary institutions". It was found that graduates who had gone through entrepreneurship programs were eager to begin their personal businesses, these changes their level of inventiveness, they urge to get their start-up capital, family foundation, trade encounter, self-efficacy, the impact of business-minded companions, introduction to entrepreneurial learning, chance affinity, age, a course considered and ethnicity. It was moreover found that EI expanded with an increment in age.

\section{The conceptual framework for the study}

The Conceptual framework proposed in this study is illustrated in Figure 1, it explains the relationship between the independent variables (Entrepreneurship education, Attitudinal factor, Subjective norms and Perceived behavioural control) and dependent variable (Entrepreneurial intention). Figure 1 presents the constructs and the hypothesized relationships.

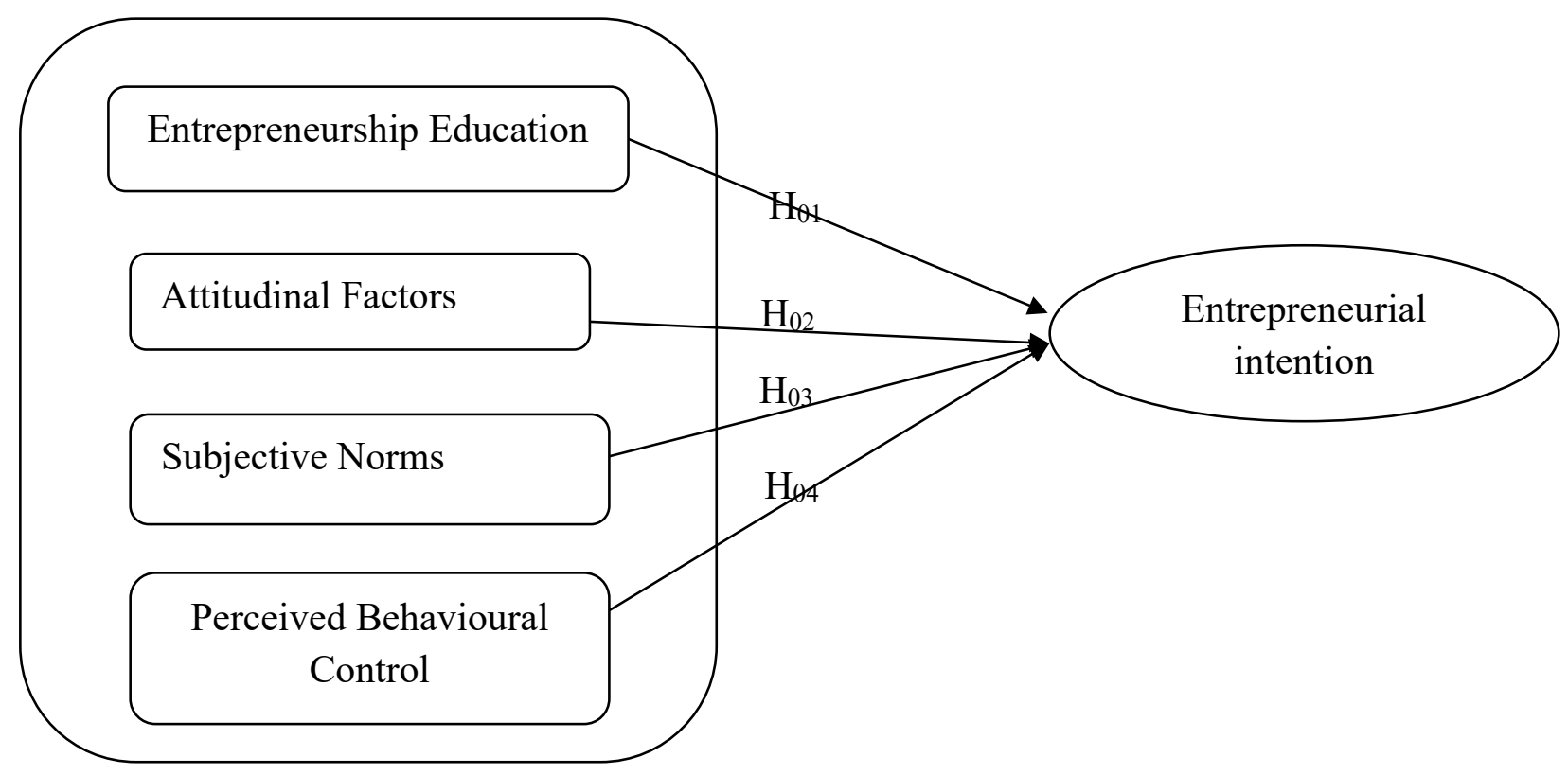

Figure 1: Conceptual framework showing the relationship between the independent variables (Entrepreneurship education, attitudinal factor, subjective norms and perceived behavioural control) and dependent variable (Entrepreneurial intention).

Source: Author's conception based on the literature reviewed. 


\section{Methodology}

A survey research design was employed in this study. The population of the study comprised of all the final year students in the School of Agriculture and Agricultural Technology of the Federal University of Technology Akure. Stratified sampling was used to divide the School into eight (8) Departments. Each of the eight Departments was considered as strata for the study. A structured questionnaire was used to collect information on EI of the students. 40 copies of questionnaires were randomly distributed to the students in each of the eight Departments. A total number of 320 copies of the questionnaire was distributed and 231 copies were retrieved for analysis. (See Table 1). The content of the questionnaire was developed from the literature (Krueger et al., 2000; Shiri, Mohammadi \& Hosseini, 2012) The questionnaire covered: EI, Entrepreneurship education, attitudinal factors, perceived behavioral control, and subjective norms. Items in the questionnaire were rated on a Likert-type scale with five possible responses for 1- strongly disagree, 2- disagree, 3undecided, 4- agree, 5- strongly agree. Descriptive statistics were used to analyze the background information of the respondents. While Linear regression analysis was used to test the hypotheses developed for the study.

\section{Model Specification}

The following linear regression model was formulated for the study

$Y=a+\beta x$

Where ' $Y$ ' is the dependent variable.

' $X$ ' is the independent variable

' $a$ ' is the constant, ' $\beta$ ' is the beta coefficient. This was repeated for the four independent variables

The results of the linear regression were shown in Table 2 and Table 3.

Table 1: Number of Questionnaires distributed and retrieved

\begin{tabular}{llll}
\hline Departments & $\begin{array}{l}\text { Questionnaire } \\
\text { Distributed }\end{array}$ & $\begin{array}{l}\text { Questionnaire } \\
\text { Retrieved }\end{array}$ & $\begin{array}{l}\text { Percentage } \\
\text { Retrieved }\end{array}$ \\
\hline Animal Production and Health & 40 & 34 & 85 \\
Agricultural Communication and Extension & 40 & 30 & 75 \\
Agricultural Resource and Economics & 40 & 28 & 70 \\
Crop, Soil and Pest Management & 40 & 27 & 65 \\
Ecotourism and Wildlife Management & 40 & 29 & 73 \\
Fishery and Aquiculture Technology & 40 & 26 & 65 \\
Forestry and Wood Technology & 40 & 29 & 73 \\
Food Science and Technology & 40 & 28 & 70 \\
Total & $\mathbf{3 2 0}$ & $\mathbf{2 3 1}$ & $\mathbf{7 2}$ \\
\hline
\end{tabular}

Source: Field survey, 2021

\section{Results and Discussion}

\section{Regression Analysis for Independent variables}

The regression coefficient for all the independent variables on the dependent variable was shown in Table 2. The result showed that a regression coefficient of all the four independent variables Entrepreneurship Education, Attitude of the Students', subjective norms and Perceived Behavioural 
Control have positive effect on the dependent variable indicating that an increase in each of the independent variables will bring about an increase in the dependent variable in the study area. Both the Bata and the significant value of all the independent variables were shown in Table 2 . The coefficient of determination $\mathrm{R}^{2}$ of entrepreneurship education was given as $(0.207)$, which means that the influence of entrepreneurship education by $20.7 \%$ of the variation in EI. The correlation coefficient (R) of 0.455 indicates the influence of the independent variable on the dependent variable. The analysis of variance (ANOVA) showing that the effect of Entrepreneurship education on the dependent variable is statistically significant. This is shown as a value of $\mathrm{P}=0.000$ which is less than the acceptable significant value of 0.05 , Hence, $\mathrm{H}_{01}$ which stated that entrepreneurship education does not have a significant effect on the EI of the students was rejected. This is in agreement with the study carried out by Tateh, Latip and Awang (2014); Khalifa and Dhiaf (2016).

Table 2: Regression Coefficients for the variables

\begin{tabular}{|c|c|c|c|c|c|}
\hline \multirow{2}{*}{\multicolumn{2}{|c|}{ Model }} & \multicolumn{2}{|c|}{ Coefficients } & \multirow[t]{2}{*}{$\mathrm{t}$} & \multirow[t]{2}{*}{ Sig } \\
\hline & & $\mathrm{B}$ & Std. Error & & \\
\hline \multirow[t]{2}{*}{1} & (Constant) & 1.964 & 0.138 & 14.191 & 0.000 \\
\hline & Entrepreneurship education & 0.271 & 0.035 & 7.740 & 0.000 \\
\hline \multirow[t]{2}{*}{2} & (Constant) & 2.351 & 0.080 & 29.554 & 0.000 \\
\hline & Attitudinal factor & 0.252 & 0.028 & 9.134 & 0.000 \\
\hline \multirow[t]{2}{*}{3} & (Constant) & 2.242 & 0.098 & 22.962 & 0.000 \\
\hline & Subjective norms & 0.240 & 0.029 & 8.360 & 0.000 \\
\hline \multirow[t]{2}{*}{4} & (Constant) & 2.655 & 0.042 & 62.687 & 0.000 \\
\hline & Perceived behavioural control & 0.116 & 0.009 & 12.796 & 0.001 \\
\hline
\end{tabular}

Source: Field survey, 2021

Table 3: Analysis of variance for independent variables

\begin{tabular}{lllllll}
\hline Variables & $\mathrm{R}$ & $\mathrm{R}^{2}$ & $\mathrm{Adj}^{2}$ & F-statistics & Std. Error & Sig level \\
\hline Entrepreneurship education & 0.455 & 0.207 & 0.204 & 59.913 & 0.5862 & 0.000 \\
Attitudinal factor & 0.517 & 0.267 & 0.264 & 83.426 & .56368 & 0.000 \\
Subjective norms & 0.484 & 0.234 & 0.230 & 69.891 & .57630 & 0.000 \\
Perceived behavioural control & 0.646 & 0.417 & 0.414 & 163.745 & 0.50275 & 0.000 \\
\hline
\end{tabular}

Source: Field survey, 2021

Educational background is one of the main factors influencing the EI among the students. The relationship investigation showed that youth EI are emphatically related to their identity characteristics (risk-taking affinity, innovativeness, and resilience of uncertainty), and social learning (information and involvement and family childhood) (Tateh et al., 2014). The entrepreneurship education program has influenced student behaviour control and anticipation of positive and negative impacts (Zampetakis, Anagnosti \& Anagnosti, 2014). The study shows that educational background in agriculture affecting the entrepreneurship intention of the students. 
Mohavedi, Latifi and Sayyar (2013) showed motives of a bachelor candidate to work in the agricultural sector. Hence, this EI tends to be prominently dominated by agriculture graduates. Respondents with agricultural backgrounds are more likely to become agri-entrepreneurs compared to the ones with social science foundations (Latip \& Awang, 2014; Khalifa \& Dhiaf, 2016). In any case, it is contrasted with research conducted by Aziz and Naem (2013) on youth interface on rural business in Malaysia, which shows that knowledge and education background is not significantly affecting those youths to be entrepreneurs.

The $\mathrm{R}^{2}$ of an attitudinal factor in Table 3 is $27 \%(0.267)$, this means that the influence of the attitudinal factor by $27 \%$ of the variation in EI. The correlation coefficient $\mathrm{R}$ of 0.517 significant effects of the independent variable on the dependent variable. The analysis of variance (ANOVA) shown a value of 0.000 which is less than the acceptable significant value of 0.05 , Hence, $\mathrm{H}_{02}$ is which stated that attitude does not have a significant effect on student's EI was rejected, this is in agreement with the study carried out by Muhammad et al., (2015), Rizki et al., (2017), found out that entrepreneurial attitude, subjective norm, and power of behavioural control are all good predictors of EI but the study was not in support of the work of Arisandi (2016) that Entrepreneurship attitude cannot determine how big intentions for entrepreneurs in the agricultural sector. Hence, the created entrepreneur's behaviour is not based on attitude toward the behaviour. Arisandi (2016) expressing that attitude toward the behaviour does not give any positive influence on the entrepreneur's intention in the agribusiness sector.

The coefficient of determination $\mathrm{R}^{2}$ of subjective norms in Table 3 is $23 \%(0.234)$, this means that the influence of the independent variables by $23 \%$ of the variation in EI. The correlation coefficient $\mathrm{R}$ is 0.484 indicates the influence of the independent variable on the dependent variable. The analysis of variance (ANOVA) showing the effect of Subjective Norms on EI is statistically significant, this is shown as a value of 0.01 which is less than the acceptable significant value of 0.05 , Hence, $\mathrm{H}_{03}$ which stated that subjective norms do not have a significant effect on the EI of the students was rejected, this is in agreement with the research conducted by Shiri et al., (2012) and Rizki et al., (2017), the subjective norm has significant influence on entrepreneur's intention of students who has agricultural education background. This factor shows how far social pressure from some sides can increase an entrepreneur's intention. Supports coming from parents, family, friends, consultants and business team affect the high intention's value. This condition is called as external factors of respondents, and it collaborates positively with the entrepreneur's intention. Confirming research conducted by Shiri et al., (2012), and Arisandi (2016) it is expressed that someone who has agricultural education background is highly influenced by the subjective norm.

The $\mathrm{R}^{2}$ of perceived behavioural in control in Table 3 is $41 \%(0.417)$, this means that the influence of the independent variable perceived behavioural is controlled by $41 \%$ of the variation in EI. The correlation coefficient (R) of 0.646 indicates the influence of the independent variable on the dependent variable. The analysis of variance (ANOVA) showing the effect of perceived behavioural control is statistically significant in explaining the effect of perceived behavioural control on EI, this is shown as a value of 0.000 which is less than the acceptable significant value of 0.05 , Hence, $\mathrm{H}_{04}$ which stated that perceived behavioural control does not have a significant effect on the EI of the students was rejected, this is in agreement with the study carried out by Masoomi, Zamani, Bazrafkan and Reza (2016) which proves that perceived behaviour control is highly correlated with EI of students in agriculture at the University of Shiraz, Iran. Likewise, Muhammad et al., (2015) study, found that attitude, subjective norm, and control behaviour power altogether to influence the EI of 
Nigerian students. A comparison study with different countries by Indrianti (2008) shows that entrepreneur's intentions among students and the affecting factors are different among those countries. Meanwhile, Arisandi (2016) observed that without any behaviour controls, respondents surely believes that the entrepreneurship's intention can appear from themselves and submitted that perceived behavioural control has no influence on entrepreneur's intention in the agribusiness sector. The study also disagreed with the study conducted by Rizki et al., (2017), which shows that the perceived behavioural control is not significant with the EI of the students.

Table 4: Summary Table of Hypotheses Tested

\begin{tabular}{llll}
\hline S/N & Research Hypotheses & Sig level & Decision Results \\
\hline 1 & $\begin{array}{l}\text { Entrepreneurship education does not } \\
\text { have a significant effect on the EI of the } \\
\text { students }\end{array}$ & Null hypothesis ( $\left.\mathrm{H}_{01}\right)$ was rejected \\
2 & $\begin{array}{l}\text { Attitude does not have a significant } \\
\text { effect on student's EI }\end{array}$ & Null hypothesis ( $\left.\mathrm{H}_{02}\right)$ was rejected \\
3 & $\begin{array}{l}\text { Subjective Norms do not have a } \\
\text { significant effect on the EI of the } \\
\text { students. }\end{array}$ & Null hypothesis ( $\left.\mathrm{H}_{03}\right)$ was rejected \\
& $\begin{array}{l}\text { Perceived behavioural control does } \\
\text { nothave a significant effect on the EI of } \\
\text { the students }\end{array}$ & Null hypothesis ( $\left.\mathrm{H}_{04}\right)$ was rejected \\
\hline
\end{tabular}

Source: Field survey, 2021

\section{Conclusion and Recommendations}

The study investigated the various factors influencing the EI of the students of Agriculture and Agricultural Technology, the Federal University of Technology, Akure, Nigeria towards entrepreneurship. Using entrepreneurial education, the attitudinal factors of the students, subjective norm and perceived behavioural control as the behavioural context leading to their EI. The results revealed that the behavioural factors are possible determinants of students' EI. Entrepreneurship education is needed in Nigeria's economy to create jobs, reduce unemployment, crime, government's expenditure, poverty, social unrest, create wealth, and raise the standard of living in the country. However, in other for the students to have a good interest in entrepreneurship, the study recommended that both the government and individuals need to support the entrepreneurs by investing in enterprise education, this will encourage the students to use the knowledge in other to creating wealth and employment opportunities. 


\section{References}

Agu, C. N. (2006). Pedagogy of entrepreneurship in contemporary society. The Enterprise International Research Journal for Development, 8(1), 18-32.

Ajzen, I. (1991). The theory of planned behavior. Organizational Behavior and Human Decision Processes, 50(2), 179-211.

Ajzen, I. (2005). Attitudes, personality, and behavior. maidenhead, berkshire, England: Open University Press.

Ajzen, I., \& Sheikh, S. (2016). Action versus inaction: Anticipated effect in the theory of planned behavior. Journal of Applied Social Psychology, 46(5), 313- 314.

Alberti, F, Sciscia, S., \& Poli, A. (2004). Entrepreneurship education; notes on an ongoing debate. Proceedings of the $14^{\text {th }}$ Annual International Entrepreneur Conference, University of Napoli Federico 11, Italy; 2004.

Al-Jubari, I. (2019). College Students' Entrepreneurial Intention: Testing an Integrated Model of SDT and TPB. SAGE Open, 9(2), 1-15.

Ali, S., Lu, W., \& Wang, W. (2012). Determinants of Entrepreneurial Intentions among the College Students in China and Pakistan. Journal of Education and Practice 3(11), 2012.

Aloulou, W. J. (2016). "Predicting the entrepreneurial intentions of final year' business students by applying the theory of planned behavior in Saudi context", Journal of Small Business and Enterprise Development, 23(4), 1142-1164.

Amadi E. A., \& Amakodi, S. E. (2019). Factors influencing the implementation of entrepreneurship education in Tertiary Institutions in Rivers State, Port Harcourt International Journal of Innovative Social \& Science Education Research, 7(2):22-36,

Amzad, H., Naser K., \& Zaman, A. (2009). Factors influencing women business development in the developing countries, international journal of organizational analysis, 17(3), 202-224

Arbuthnott, D. K. (2008). Education for sustainable development beyond attitude change. International Journal of Sustainability in Higher Education 10(2), 152-163.

Arisandi, D. (2016). Intensi Berwirausaha Mahasiswa Pascasarjana Institut Pertanian Bogor Pada Bidang Agribisnis (Studi Kasus Pada Mahasiswa Program Magister Sps-Ipb), Thesis, Bogor Agricultural University, Bogor, ID.

Awogbenle, A. C., \& Iwuamadi, K. C. (2010). Youth unemployment: Entrepreneurship development programme as an intervention mechanism. African Journal of Business Management, 4(6), 831835 .

Ayatse, F. A. (2013). Driving Entrepreneurship Education in Nigeria: Issues and Challenges. International Journal of Business and Management Review, 1(4), 83-90.

Ayeduse, A. O. (2011). Entrepreneurial education in E.C. Osuala (Ed) Principles and methods of business and computer education, Nsukka: God Jikson Publisher. 
Aziz, A., \& Naem, N. (2013). Factors that influence the interest of youths in agricultural entrepreneurship, International Journal of Business and Social Science, 4(3), 288-302.

Egbefo, D. O., \& Abe, M. O. (2017). Entrepreneurship education: A vital instrument for youth empowerment, industrial development and consolidation of national integration in Nigeria. International Multi-disciplinary Journal, Ethiopia, 11(1), 28-48.

Cromie, S. (2000). Assessing entrepreneurial inclinations: Some approaches and empirical evidence. European Journal of Work and Organizational Psychology, 9(1), 7-30.

Douglas, E. J., \& Fitzsimmons, J. R. (2005). Entrepreneurial Intentions towards individual vs. Corporate entrepreneurship. Paper presented at the SEAANZ 2005 Conference, Armidale, N.S.W., September.

Farooq, M. S., Salam, M., Fayolle, A., Jaafar, N., \& Ayupp, K. (2018). Impact of service quality on customer satisfaction in malaysia airlines: A PLS-SEM approach. Journal of Air Transport Management, 67(1), 169-180.

Fayolle, A., \& Gailly, B. (2015). The impact of entrepreneurship education on entrepreneurial attitudes and intentions: hysteresis and persistence, Journal of Small Business Management, 53(1), 75-93.

Fayolle, A., Gailly, B., \& Lassas-Clerc, N. (2006). Assessing the impact of entrepreneurship education programmes: a new methodology. Journal of European industrial training.

Ehsan, M., Naser, Z., Khadijeh, B., \& Mohammadreza, A. (2016). An investigation of the factors influencing entrepreneurial intention of senior agricultural students at Shiraz University, Iran. International Journal of Agricultural Management and Development, 6(4), 431-437.

Emmanuel, S. O., Adejoke, B. K., Olugbenga, O. V., \& Olatunde, L. O. (2012). Entrepreneurial intention among business and counseling students in Lagos State University Sandwich Programme. Journal of Education and Practice 3(14).

Emeraton, U. G. (2008). Re-thinking higher education management for poverty reduction among the youth in Africa. Paper presented at the 3rd Regional Conference of Higher Education for Youth Empowerment, Opportunities, Capabilities and Second Chance. Organized by Higher Education Research and Policy Network (NERPNET) at IITA, Ibadan, Oyo State. August 18-21.

Entrialgo, M., \& Iglesias, V. (2016). The moderating role of entrepreneurship education on the antecedents of entrepreneurial intention. International Entrepreneurship and Management Journal, 12(4), 1209-1232.

Enu, D. B. (2012). Enhancing the entrepreneurship education in Nigeria. American Journal of Social Issues and Humanities, 2(4), 232-239.

Gelderen, V. M., Brand, M., Praag, V. M., Bodewes, W., Poutsma, E., \& Gils, V. A. (2008). Explaining entrepreneurial intentions using the theory of planned behaviour", Career Development International,13 538-559.

Idris, A. A. (2017). Entrepreneurial Intention among Postgraduate Students in Nigerian Universities: Conceptual Review. American Finance \& Banking Review. 
Liñán, F., \& Chen, Y. W. (2009). Development and cross-cultural application of a specific instrument to measure entrepreneurial intentions. Entrepreneurship Theory and Practice. 33.593 - 617.

Liñán, F., \& Fayolle, A. (2015). A systematic literature review on entrepreneurial intentions: citation, thematic analyses, and research agenda. International Entrepreneurship and Management Journal, 11(4), 907-933.

Indrianti, R. (2008). Intensi Kewirausahaan Mahasiswa, Studi Perbandingan antara Indonesia, Jepang dan Norwegia, Jurnal Ekonomika dan Bisnis Indonesia, 10(1), 91-110.

Kenneth, C. A., Godday, O. O.. \& Michael, O. (2013). Factors influencing entrepreneurial intentions among graduates of Nigerian tertiary institutions. International Journal of Business and Management Invention. 2(4), 36-44.

Khalifa, A. H., \& Dhiaf, M. M. (2016). The impact of entrepreneurship education on entrepreneurial intention: The UAE context. Polish Journal of Management Studies. 14(1), 119-128.

Kolvereid, L. (1996). “Organisational Employment Versus Self-Employment: Reasons for Career Choice Intentions". Entrepreneurship Theory \& Practice 20: 23-31.

Kristiansen, S., \& Indarti, N. (2004). Entrepreneurial Intention Among Indonesian and Norwegian Students. Journal of Enterprising Culture, 12, 55-78.

Krueger, N., Reilly, M., \& Carsrud, A. (2000). Competing models of entrepreneurial intentions. Journal of Business Venturing, 15(5), 411-432.

Liñán, F. (2004). Intention-Based Models of Entrepreneurship Education. Piccola Impresa / Small Business. 11-35.

Masoomi, E., Zamani, N., Bazrafkan, K., \& Reza, M. (2016). An investigation of the factor influencing entrepreneurial intention of senior agricultural students at Shiraz Univerity, Iran", International Journal of AgriculturalManagement and Development, 6(4), 431-437.

McGee, J. E., Peterson, M., Mueller, S. L., \& Sequeira, J. M., (2009). Entrepreneurial self-efficacy: refining the measure. Entrepreneurship Theory and Practice. 33(4), 965-988.

Mohammed, M., \& Aparna, M. P. (2011). Entrepreneurial Intentions of MBA Students - A Study in Hyderabad. Entrepreneurial Practice Review, 1(4), 20-37.

Mohavedi, R., Latifi, S. \& Sayyar, L.Z. (2013). The factors affecting agricultural students attitude towards self-employment and entrepreneurship, International Journal of Agriculture and Crop Sciences, 5(15), 1813-1819.

Muhammad, A. D., Aliyu, S., \& Ahmed, S. (2015). Entrepreneurial intention among Nigerian University students. American Journal of Business Education, 8(4), 239-247.

Nahida, S., \& Md, T. R. (2020). Explaining entrepreneurial intentions of international students in Sweden by means of the theory of planned behaviour. Unpublished M Sci. Theses Halmstad University.

National Implementation Plan (2010) The first National Implementation Plan 2010-2013, Vol III: Sectorial plan and programmes. 
Nematoollah, S., Davoud, M., \& Seyed M. H. (2012). Entrepreneurial intention of agricultural students: Effects of role model, Social support, social norms and perceived desirability. Archives of Applied Science Research, 4(2), 892-897.

Odoemelam L. E., \& Maduka. O. A. (2017). Unlocking the entrepreneurial potentials of undergraduates in the Michael Okpara University of Agriculture, Umudike Nigeria: The Role of Lecturers. Journal of Economics, Management and Trade 20(2), 1-9.

Okojie, J. A. (2009). Imperative of the federal government directive on the establishment of entrepreneurship studies in Nigerian Universities, A paper presented at the $1^{\text {st }}$ conference on effective implementation of federal government seven-point Agenda held at NUC, Abuja, Feb.4-6.

Ozaralli, N., \& Rivenburgh, N. K. (2016). Entrepreneurial intention: antecedents to entrepreneurial behavior in the U.S.A. and Turkey. Journal of Global Entrepreneurship Research, 6(1), 1-32.

Pajares, F. (2002) Overview of social cognitive theory and self-efficacy. Retrieved May 25, 2020, from http://www.des.emory.edu/mfp/eff.html.

Potishuk, V., \& Kratzer, J. (2017). Factors affecting entrepreneurial intensions and entrepreneurial attitudes in higher education. Journal of Entrepreneurship Education. 20. 25-44.

Purusottama, A. (2019). Revisiting Students Entrepreneurial Intention in Indonesia: a theory of Planned Behavior Approach. Jurnal Manajemen dan Kewirausahaan, 21(1), 64-73.

Rizki, N. R, Burhanuddin, N., \& Budi, W. (2017). Entrepreneurship intention in the agricultural sector of the young generation in Indonesia. Asia Pacific Journal of Innovation and Entrepreneurship, 11(1), 76-89.

Shiri, N., Mohammadi, D., \& Hosseini. S. M. (2012). Entrepreneurial intention of agricultural students: effects of role model, social support, and perceived desirability. Journal of Archives of Applied Science Research, 4(2), 892-897.

Siyanbola, W. O., Afolabi, O. O., Jesuleye, O. A., Egbetokun, A. A., Dada, A. D., Aderemi, H. O., Sanni M., \& Razak, M. (2009). Determinants of the entrepreneurial propensity of Nigerian undergraduates: an empirical assessment. International Journal of Business Environment, Inderscience Enterprises Ltd, 5(1), 1-29.

Tateh, O., Latip, H. A., \& Awang M. D. A. (2014). Entrepreneurial intentions among indigenous Dayak in Sarawak, Malaysia: an assessment of personality traits and social learning The Macrotheme Review, 3(2), 110-119.

Usman, B., \& Yennita (2019). Understanding the entrepreneurial intention among international students in Turkey, Journal of Global Entrepreneurship Research, 9(1), 1-21.

Wan, C., Shen, G. Q., \& Yu, A. (2014). The role of perceived effectiveness of policy measures in predicting recycling behavior in Hong Kong. Resour. Conserv. Recycl, 83, 141-151.

Wilson, F., Kickul, J. and Marlino, D. (2007). Gender, Entrepreneurial Self-Efficacy, and Entrepreneurial Career Intentions: Implications for Entrepreneurship Education. Entrepreneurship Theory and Practice. 31. 10.1111. 
Yeboah, A., Kumi, E., \& Jacob, B. A. (2013). An assessment of entrepreneurship intention among Sunyani Polytechnic Marketing Students. International Review of Management and Marketing 3(1)37-49.

Zaki, A., Abdul, R. A. R., Kushairi, A., \& Fansuri, E. (2017). Agribusiness entrepreneurial intention among Generation Y: The role of personality traits. International Journal of Advanced Biotechnology and Research, 8(3),190-196.

Zampetakis, L., Anagnosti, A., \& Anagnosti, A. (2014). Understanding the entrepreneurial intentions of students in agriculture and related sciences. Poster paper prepared for presentation at the EAAE 2014 Congress 'Agri-Food and Rural Innovations for Healthier Societies', Ljubljana, August 26-29. 